\title{
The impact of artistic circles on the way of using and arrangement apartments in multi-family residential buildings in Poland in the 1950s and 1960s Part I - Development of architectural project ideas
}

\author{
Marta Kruk \\ Faculty of Architecture, Bialystok University of Technology, \\ krmarta@wp.pl, ORCID:0000-0002-9703-0833
}

\begin{abstract}
This article (part I) presents the activities of artistic circles - architects - and their impact on the ways of using and arrangement of the living area. The way of using apartment is understood as:

1) The way of arranging basic living functions by inhabitants (sleeping, resting, preparing and eating meals, receiving guests, studying, personal hygiene);

2) The relationships between inhabitants and an apartment dependent on education, occupational structure, origin, life style, inherited cultural patterns, fashion as well as a group of physical characteristics and apartment attributes);

3) The rights of family members to use the apartment space, including the right to intimacy and having own private space, as well as the representative needs.

The aim of this article is to show the evolution of design thinking in the field of functional and spatial layouts of apartments and indicating the main trends of these changes. The selected functional layouts of apartments (including the remarks of the author of the design), representative of the given period of time, have been analyzed with respect to social and political conditions. In summary, the most important tendencies, which may be observed in respect of discussed changes, have been indicated. These include:

- expanding the living-room area of the apartment by designing a kitchen closer to the living-room or even combining a kitchen with a living -room;

- the differentiated approach to the issues of creating sleeping areas due to the understanding of children's individual needs to have their own living space;

- the concern to upgrade the quality of hygiene in an apartment - by creating separate restrooms and designing bathrooms with a space for a washing machine.
\end{abstract}

Keywords: the use of the apartment, upgrades of modern housing, the factors affecting the use of housing

\section{Introduction}

Contemporary functional and spatial layouts of apartments in the vast majority present a model of the kitchen open to the living room. Architects try to obtain the most optimal spatial solutions often in very small spaces, and the adopted model of shaping the daytime zone in the apartment aims to provide users with a sense of greater space. The question arises whether the design of the apartments will be based only on the kitchen model in the form of an annex open to the living room and whether the process of developing design thought in 
this area has been completed. One can trace the evolution of the effects of creative environments (architects), which could lead to contemporary design solutions.

In Poland in the mid-1950s a large-scale campaign to improve the quality of home furnishings began. With the support of the then authorities, it was possible to introduce significant changes in the rather outdated layouts of apartments in typical buildings. It was important that rational furnishing of the apartment gave even in the most humble conditions the opportunity to improve housework and improve the quality of rest. Creative environments - architects, interior and furniture designers, publicists - have focused their efforts on creating a friendly, functional living space, i.e. housing, which would ensure a sense of security and the opportunity to cultivate the values important in organizing life.

The subject of this article is the activities of architects (over the 1950s and 1960s) and its impact on the use and arrangement of living space. A definition of how the apartment is used should be defined, and it is understood as:

- how users organize basic life functions (sleep, rest, preparation and consumption of meals, receiving guests, learning, playing, and hygienic activities);

- relations between users and the apartment depending on:

- education, professional structure, origin, lifestyle, inherited cultural patterns, fashion;

- a set of physical features and attributes of the apartment (functional and spatial layout, room structure, surface standard, technical equipment in installations and devices) conditioning the possibilities of meeting the needs of users;

- the rights of family members to use the space of the apartment, including the need for intimacy and to have their own private space and representative needs, including the desire for prestige and acceptance in a given social circle.

The way the apartment is used is influenced by factors independent of the household (political and legal, civilization-related) and dependent factors, such as: family structure, level of education, financial status, occupation, cultural patterns derived from the previous environment, values important in the organization of functions in the apartment, the influence of contemporary designs and fashion.

This article - Development of architectural project ideas - is the first part of a broader description of the impact of creative environments on the use and arrangement of housing. The second part shall provide for an analysis of interior design as a result of the work of interior designers, furniture, journalists, and guide authors. The purpose of the article - Part I - is to present the architectural evolution of design thought in the field of shaping functional and spatial layouts of apartments and to indicate the main trends of introduced changes.

Applied methodology:

- query including recognition and analysis:

- housing related literature;

- Polish trade magazines;

- contents of legal acts regarding the design of apartments in multi-family housing;

- CSO data (statistical yearbooks);

- research into designs of functional and spatial systems characteristic of a given research period against the background of socio-political conditions. The authors' comments - Helena and Szymon Syrkus [1] and Oskar Hansen [2] - about the spatial solutions of the apartments they proposed were also used to describe these phenomena. 


\section{Socio-cultural conditions of housing construction}

In the 1950s and 1960s, there was an almost twofold increase in urban population in Poland - from 8.9 million in 1949 to 17 million in 1970 [3]. The large demographic boom in the 1950s and labor migrations of rural residents to cities contributed to this. The cities became a mixture of the influx population, the first-generation burghers and the "old" middleclass. There was a division of society into the working class and intelligentsia, and the structure of employment was dominated by industrial workers, who constituted as much as $93.5 \%$ of the population in cities in 1956 . People with higher and secondary education (whitecollar workers) constituted only $6.5 \%$ in 1956 and $16.1 \%$ in 1970 [4], [5].

According to settlement research of the Institute of Housing ${ }^{1}$ (Instytut Budownictwa Mieszkaniowego IBM) most of the residents of the new housing estates were young married couples with preschool and school children. About $50 \%$ of mothers worked professionally at the time. Nurseries and kindergartens, as well as older women who were not professionally active outside the home provided help in raising children. Often, two generations of married couples lived in one flat: parents and children, parents and their adult children and grandchildren. Equally frequent was the forced sharing of an apartment with another, unrelated family, which took place until the liquidation of forced housing in the late 1950s.

The families of blue-collar and white-collar workers differed in cultural patterns habits, customs, in general - in the lifestyle. However, the working-class family, like the family of a white-collar worker, increasingly read books and listened to the radio. Young people studied in almost every home. Children from working-class families became whitecollar workers in high school and college. "The two »lifestyles« are getting closer and closer together. On the other hand - in relation to the pre-war period - the »lifestyle« of the white collar family has become more simple and strict. The work of women outside the home, with almost complete absence of paid domestic help, at that time put side-by-side the issue of toil with household activities in both a working-class and intellectual families. Therefore, the lifestyle, which has long existed in the environments of hard-working people, is now also transferred to the family of an average-paid white-collar worker [9]".

Aleksander Matejko, referring to research conducted in the years 1950-1956 by the Institute of Housing (IBM) [10] emphasized that the move to new settlements for all studied families was a breakthrough event. Obtaining a new, own apartment after years spent in often difficult housing conditions, after many years of waiting, caused enormous emotional experiences, feelings of joy and enthusiasm. There was readiness not only for the modernization of the household again, but also for wider changes and reorganization of the family and personal life itself [11].

The architects faced the challenge of creating decent housing for thousands of families. Among the designers were excellent artists - to name a few, the members of the pre-war Praesensu: Barbara and Stanisław Brukalski, Bohdan Lachert, Roman Piotrowski, Helena and Szymon Syrkus and Józef Szanajca. Later, others also got involved: Oskar Hansen, Maria and Kazimierz Piechotek, Halina Skibniewska, and Zofia Fafius. Sensitivity to the social impact of architecture was of great importance. Already before the war, it was postulated to build widely available, cheap and small apartments, in buildings designed from prefabricate, using new construction techniques and technologies.

\footnotetext{
${ }^{1}$ Since the beginning of the 1950 s, the Institute of Housing has commissioned research to obtain information on the quality of life in housing estates and how to use housing, preferences and suggestions from users. The study was conducted by Wanda Litterer in 1949-1950 [6], Aleksander Matejko in 1956, Władysław Malicka in 1956 [7], Wanda Czeczerda [8].
} 


\section{Political conditions, norms and functional arrangements of apartments}

After World War II, the Polish state assumed the obligation to finance housing, and the goal was to provide each family with independent housing. Widespread impoverishment of the society, awareness of the constant shortage of apartments, as well as the belief that in order to quickly meet housing needs it was necessary to make the most of the production potential - they made the decision to introduce a housing design standard [12].

\subsection{Functional layouts of apartments according to the norms of 1947 and 1951}

The first arrangements for the housing standards were introduced by the act of July 3rd, 1947 "On building norms and standards" [13]. It was set at a level close to the assumptions of the pre-war "socially needed housing" [14]. The binding sizes of five basic categories of apartments - P, PK, 2PK, 3PK, 4PK - have been established. The smallest ( $\mathrm{P}$ - room with a kitchenette) had $22 \mathrm{~m}^{2}$, the largest $58 \mathrm{~m}^{2}$ of usable area (an increase of up to $10 \%$ was allowed.) The unit standard of $11 \mathrm{~m}^{2}$ per inhabitant (approx. $7 \mathrm{~m}^{2}$ of living space) resulted from these recommendations. The surface of the apartment for 4 people - 2.5 or 3 - rooms could not exceed $41 \mathrm{~m}^{2}$.

In 1951, a norm was developed [15] which increased the number of categories and variants of apartments (from 5 to 10) and strictly defined the layout of the rooms in the apartment and the boundaries of the area for individual rooms. It also increased the usable floor space of flats - from 41 to $50 \mathrm{~m}^{2}$. In the first half of the $1950 \mathrm{~s}$, as a result of the use of housing standards (from 1947 and 1951), characteristic functional layouts of flats developed, which became typical for housing estates implemented by ZOR (Zakładowe Osiedla Robotnicze, company towns) throughout the country: mainly small - 1,2, 3-room apartments, with a relatively large kitchen.

An example would be a housing estate in the Muranów district in Warsaw, designed by architect Bohdan Lachert [16]. These were flats in the standard $10 \mathrm{~m}^{2}$ of living space per person and with one sleeping space in the kitchen, so the kitchens had to be large: $7.8 \mathrm{~m}^{2}$; $8.8 \mathrm{~m}^{2}$ and $9.8 \mathrm{~m}^{2}$ (Fig. 1a).

In turn, when designing the Praga II housing estate in Warsaw (implemented by ZOR according to the design of architect Jerzy Gieysztor and his colleagues) [17], flats in the standard $9 \mathrm{~m}^{2}$ living space per person, from studios to 4-5 rooms with kitchen, equipped with : bathrooms, central heating, radio and telephone network (!) and lifts in buildings with over 5 floors. Typical ZOR layouts of apartments are of two types:

- with a large kitchen, in which it is possible to insert a dining table and bathrooms with a sink, and even a separate toilet: PK $-34.1 \mathrm{~m}^{2}$ and $2 \mathrm{PK}-32.5 \mathrm{~m}^{2}$ and $40.9 \mathrm{~m}^{2}$ (Fig. 1b);

- with a more modest kitchen area (small, only with a window cabinet) and a bathroom without a sink: PK $-33.2 \mathrm{~m}^{2}$ and $38.3 \mathrm{~m}^{2}$ and $2 \mathrm{PK}-51.5 \mathrm{~m}^{2}$ (Fig. 1c).

This indicates that designers were seeking optimal solutions to satisfy two groups of residents: working-class families and white-collar workers who represent different cultural patterns of housing use. In their minds, workers from rural environments needed a large, multi-functional kitchen, while intellectual families needed larger rooms. Small kitchens meant that eating everyday meals moved to the room, which was not accepted in rural families. In the families of white-collar workers, however, the rooms were used for studying, parents' work, rest and the size of these rooms did not satisfy the residents. What became apparent is that with culturally extreme patterns, universal housing could not be created. 
a)

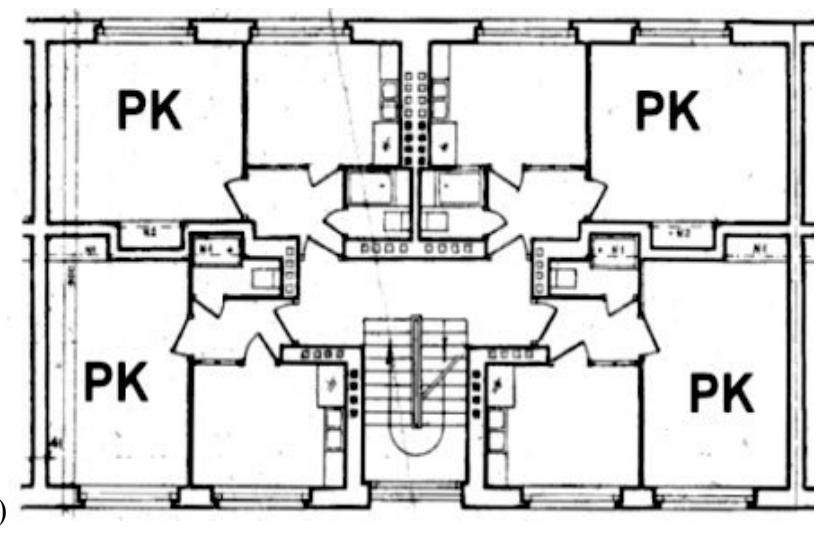

b).
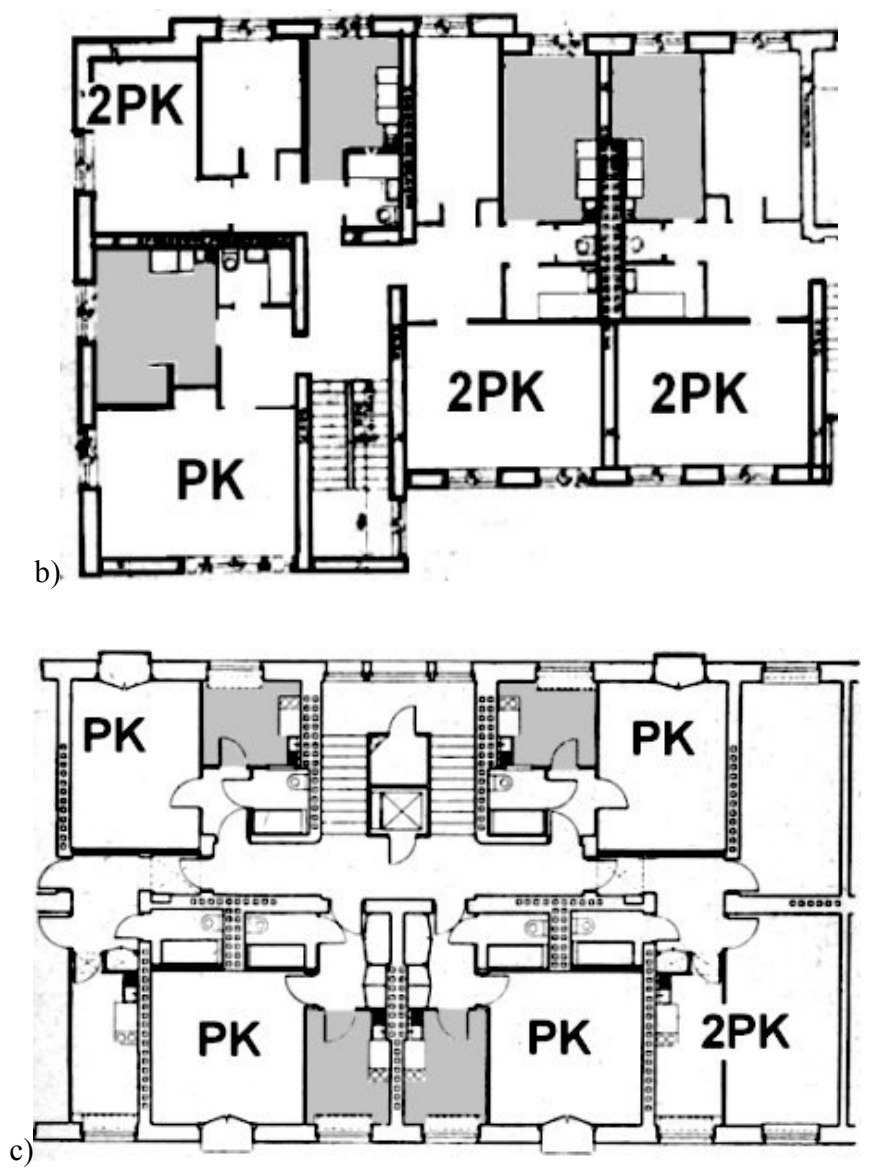

Fig. 1. Repetitive sections of buildings: a) in Muranów, 1949r., b), c) Praga II housing estate, 1952; Source: own study based on [16], [17] 


\subsection{Search for flexible functional layouts of apartments designed according to the 1954 norm}

The next norms were introduced by the Resolution of the Presidium of the Government on February 6, 1954 [18]. This change brought a reduction in the number of apartment categories to five, but increased the living space in relation to the usable floor space. This was to serve greater flexibility in the use of apartments. From 1956, studies and the search was intensified for new, more functional solutions which, according to architects - for example Zygmunt Kleyff, Helena and Szymon Syrkus, Zofia Fafius - would be adequate to the needs of a modern family.

In addition to the traditional technology used in multi-family housing, the architects began to look for more modern methods of erecting buildings, enabling faster and cheaper construction of a large number of apartments. The housing estate at Kasprzaka Street in Warsaw was the so-called experimental estate designed by architect Zygmunt Kleyff and a team of his colleagues [19]. Implementation of the project, the work on which had started in 1955, took place in 1957. Two prototype large-panel buildings were created, in which a modular mesh and a catalog of elements of several stylized and unchangeable functional, constructional and installation nodes were created.

The apartments were designed on the basis of the1954 norm: PK apartments (for 2 people) with a usable area of $37.2 \mathrm{~m}^{2}$ and $30.6 \mathrm{~m}^{2}, 2 \mathrm{PK}$ (for 4-5 people) with a usable area of $48.6 \mathrm{~m}^{2}$ and $58.4 \mathrm{~m}^{2}$ and 3PK (5-6 people) with a usable area of $74.8 \mathrm{~m}^{2}$ and $60.4 \mathrm{~m}^{2}$ (Fig. 2a, b).

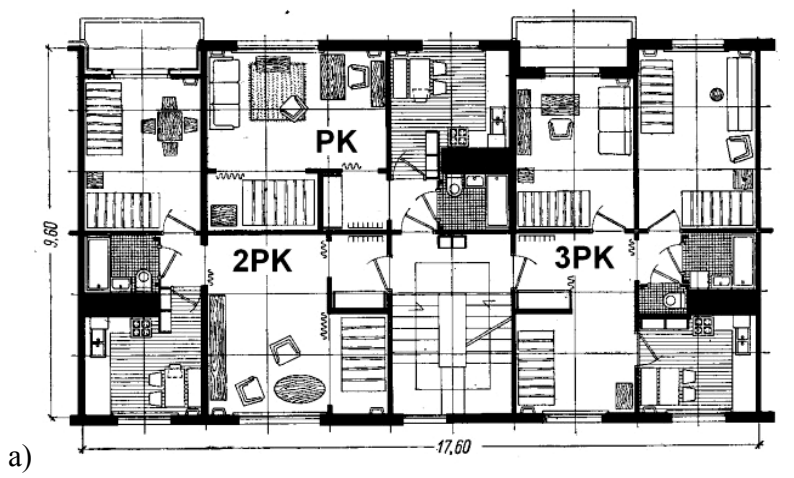

a)

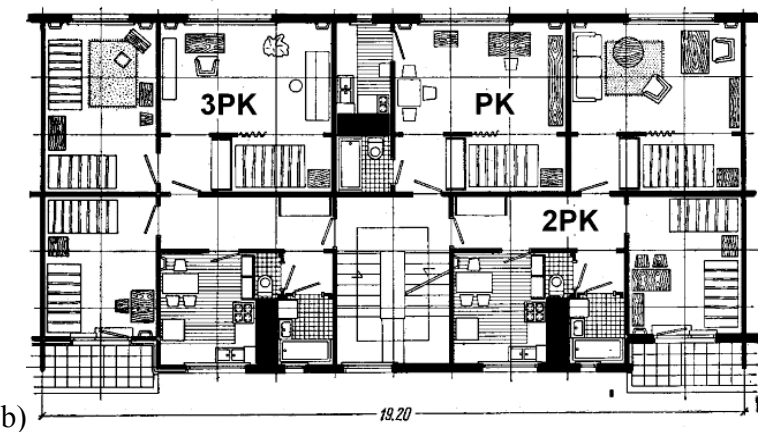

Fig. 2. a), b). Floor plans of apartments Kasprzak housing estate, 1957. Source: own study based on [19] 
The following solutions proposed by the team of Zygmunt Kleyff pay attention to the layouts of flats:

- a kitchen with an arranged place to eat, which was a response to the clear preferences of users;

- bedroom areas in the living rooms (after opening them to the living room, more space could be obtained;

- the use of two systems: traditional, in which individual rooms are entered from a separate hall; and non-traditional, in which the living room space from the entrance connects with communication, sometimes with the kitchen, which is a new, more open approach to the living area of the apartment (Fig. 2b);

- the introduction of larger bathroom blocks in the apartments (3PK) with a separate toilet, which allowed to put a washing machine in the bathroom.

a)

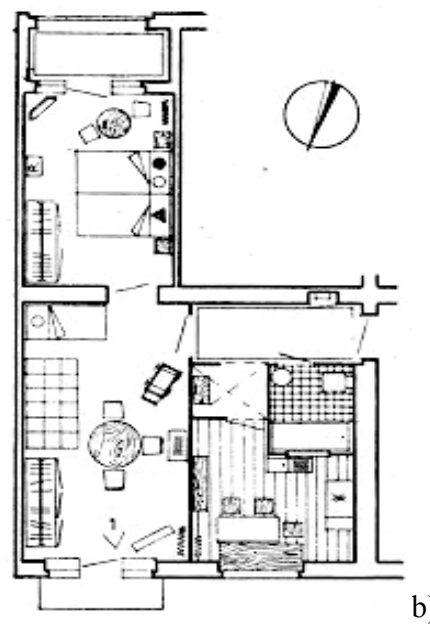

b)

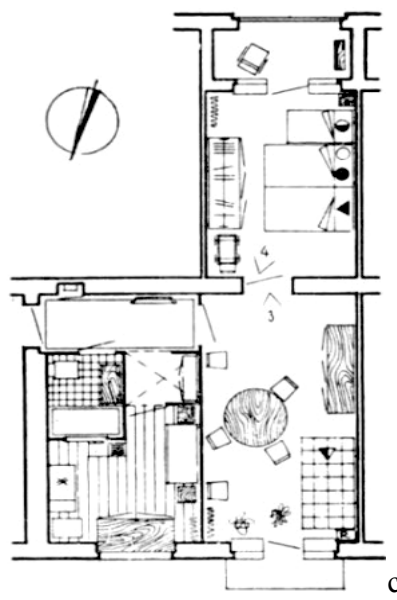

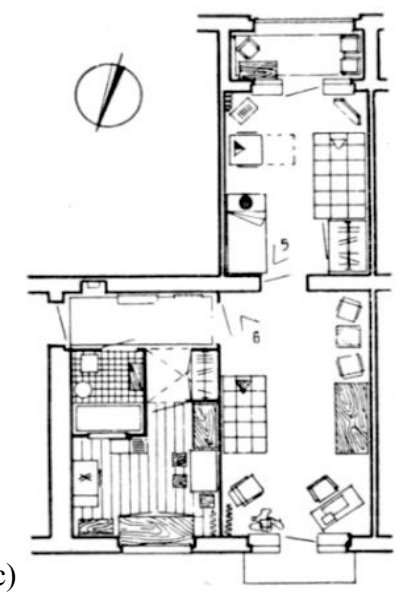

Fig. 3. The way of using the apartment: a), b) - workers' and c) - white-collar, Nowa Huta housing estate, 1956. Source: own study based on [20]

To understand how revolutionary solutions for interior design were proposed by architects, one should compare the way of organizing space in the flats of working-class and intellectual families at that time [20]. The family sleeps in the bedroom, and the representativeness of the living room comes first in the hierarchy of values. It is acceptable for a small child or older learners to sleep there. At the very least, separate beds are dedicated in white-collar family apartments (Fig. 3a -c). Architects attempted to change the housing awareness of tenants, but cultural patterns derived from previous environments were strongly established.

In the industrialized technology, a housing estate on Koło in Warsaw, designed by architects Helena and Szymon Syrkus, was implemented in 1947-1962. Noteworthy is the designers' care about the variety of spatial solutions of apartments depending on the composition of the family. "We also wanted to achieve much more freedom of various shapes of apartments in the same category using a permanent assortment of structural elements than in the 1955 series. In this way, we could provide future tenants the possibility to choose the type of apartment that best suits their needs within the same or similar usable area $\left(11 \mathrm{~m}^{2}\right.$ per person). As housing cooperatives develop, building not for an anonymous recipient, but for 
predetermined families, the selection of the right apartment can be made before the building is erected on the basis of clearly legible projects or, as we have postulated for many years, on the basis of furnished scale models $1: 1$ "[1].
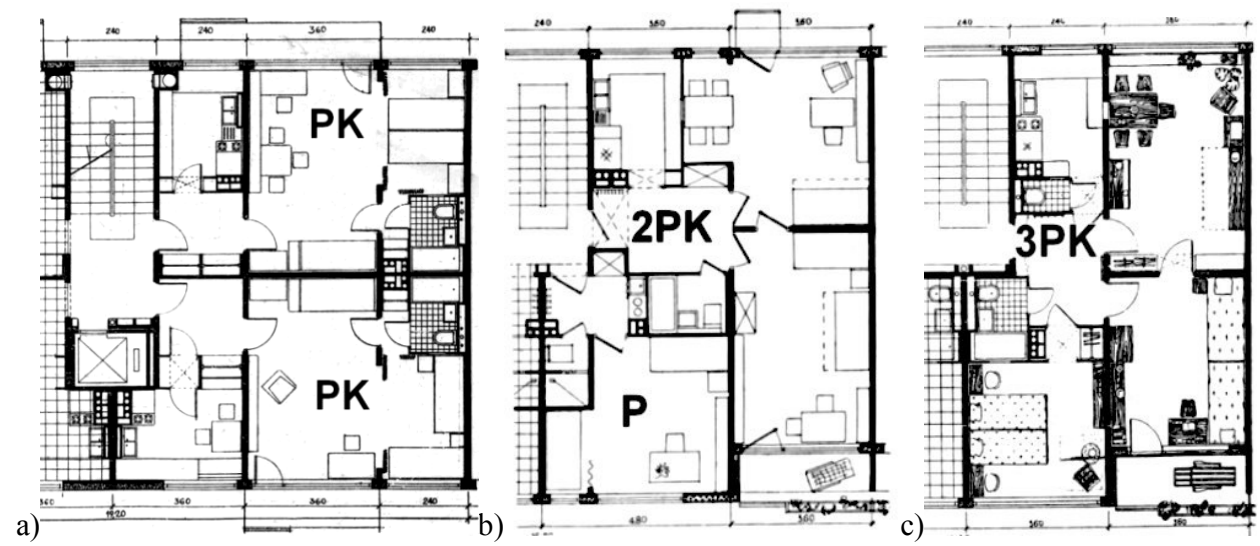

Fig. 4. Floor plans of the Koło housing estate, Warsaw, 1957. Source: own study based on [1].

The apartments' designs use:

- the separation of sleeping niches in PK type apartments (for 3 people) with an area of $42.1 \mathrm{~m}^{2}$ and $44.2 \mathrm{~m}^{2}$ whose area, according to the norm from 1954, was the area of 2PK type apartments (Fig. 4a); notable is the position the sleeping niche in the immediate vicinity of the bathroom - after closing the niche, the toilet can be used directly;

- connecting space by placing doors also between rooms (Fig. $4 \mathrm{~b}, \mathrm{c}$ ): $3 \mathrm{PK}-65.4 \mathrm{~m}^{2}$ usable and $2 \mathrm{PK}-53.2 \mathrm{~m}^{2}$ of usable space;

- locating the kitchen in the vicinity of the living room, which was not yet an obvious and popular solution, and connecting it through the supply window (Fig. 4b, c).

Three different approaches to the arrangement of sleeping places can be noted probably the result of a clash of views on this topic and the issue of the child's place in the space of the apartment:

- parents' bedroom annexes are separated, and an additional sleeping place is provided in the living room - probably with a child in mind, which is not a comfortable solution (Fig. 4a);

- the children have their own room, while the parents occupy fold-out beds in the living room (Fig. 4b);

- a favorable solution in which parents have a separate bedroom and children have their own room in a 3PK apartment with a usable area of $65.4 \mathrm{~m}^{2}$ (Fig. 4c).

The housing needs of children were considered by Zofia Fafius and the team when designing the Wierzbno housing estate in Warsaw - Wierzbno B, which was implemented in 1956-57 in large-block technology [21]. In the proposed apartments, the following design and arrangement decisions are noteworthy:

- placing sleeping areas with the care for parents 'comfort, creating a bedroom even in the vicinity of sanitary blocks (Fig. 5b), and placing additional beds in the living room (for children), or on the contrary - placing parents' sleeping place in the living room, and leaving children their own rooms (Fig. 5a) according to the emerging 
contemporary pattern. As can be clearly observed, the designers were still struggling to adopt one concept, and the spatial needs of children are voiced;

- introducing an open space by connecting the hall, living room and sleeping area and obtaining the maximally increased interior space (Fig. 5b).

a)

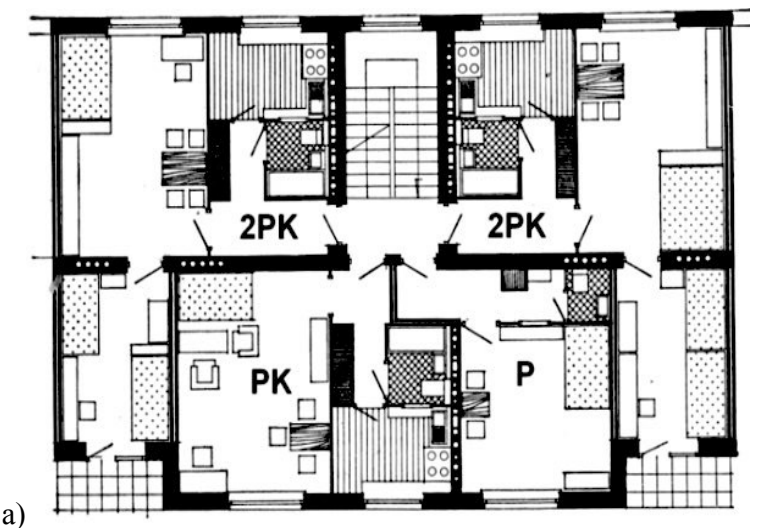

b)

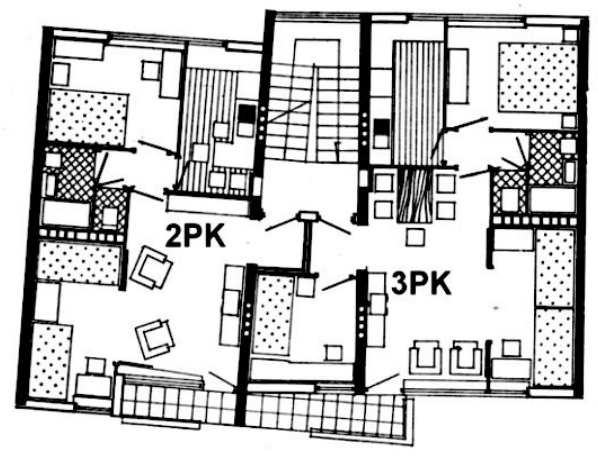

Fig. 5. a), b). Plans of apartments in the Wierzbno housing estate in Warsaw, 1957. Source: own study based on [21]

An example of a special concern of designers for improving the quality of life of residents as units with individual needs and a specific housing culture was to be the WSM (Warsaw Housing Cooperative) housing estate in Rakowiec. The project of Oskar and Zofia Hansen's housing estate, based on the guidelines of the housing norm from 1954, was completed in 1959. "To create for EVERYONE the best place in the housing estate, it is best to form an apartment for them - conditions for their otherness, for their reflexes - that was the motto of the WSM Rakowiec. [...] give the widest choice possible! So maximum diversity while maintaining most stylized building elements. [...] clear differentiation of the situation of individual residential divisions and ultimately different treatment of a particular apartment will give the opportunity to really perceive it as "one's own apartment" [2].

Oskar Hansen designed the apartments individually, even taking into account the profession of users. The seamstress could live in a one-sided apartment, where there are no drafts (scraps of materials would not spread throughout the room), and in turn a large family would receive a double-sided apartment, easily ventilated due to the smells of meals cooked in larger quantities. The designer considered the right model of the laboratory type kitchen, 
and the table was located in the vicinity of the kitchen, which is sometimes opened to the living room in the apartments PK (Fig. 6a) and 3PK (Fig. 6b).
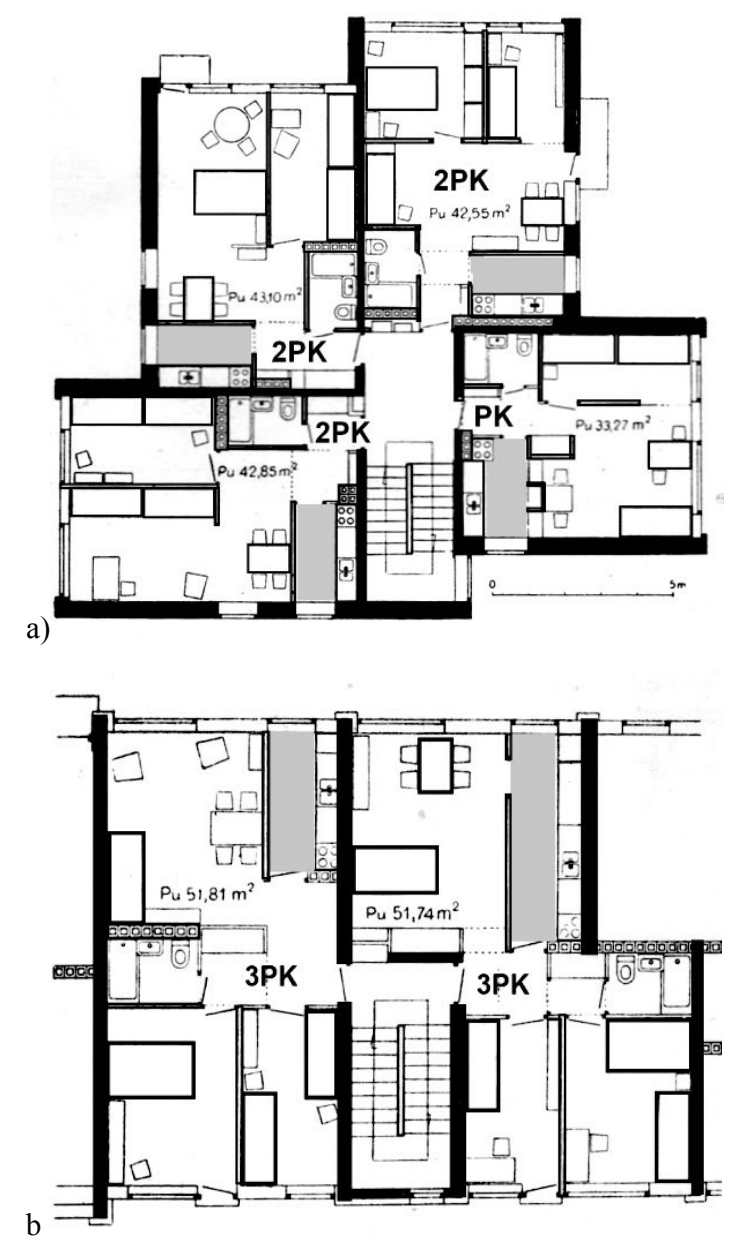

Fig. 6. a), b) Views of apartments in Rakowiec, 1959. Source: own study based on [2]

"This approach has resulted in a wide range of spatial solutions for apartments. The principle of separating in the apartment the part intended for living functions - linking the living room with the kitchen and with the intention of bringing together the place of preparation of the meal and the place to eat - and separating the individual spaces - sleeping rooms, tying them with the bathroom. [...] We thought that first and foremost good equipment of the economic part was important. Saving time and effort in homework gives a social profit in relation to the expenditure on the device and finishing the apartment. Kitchen equipment corresponding to the correct organization of the working process: wardrobe or a place for a fridge to store products, a sink with a drip plate, a work table, a gas stove, a place to put away the pots, and introducing hanging cupboards in addition to the bottom ones. The singlerow system was found to be the most convenient for the assembly of stylized elements and for the user. Great emphasis was also placed on placing the right number of built-in cabinets "[2]. 
In the years 1957-1964 Bielany II and Bielany III housing estates were created. Designed by Maria and Kazimierz Piechotka - after the so-called Gomułka's thaw - were already examples of reviving modernism. It was a period when houses with a characteristic shape were created: with gable roofs with gently sloping surfaces, two-colored brick facing arranged in the so-called Bielany brickwork and the characteristic prefabricated windows with black frames and white sashes [22].
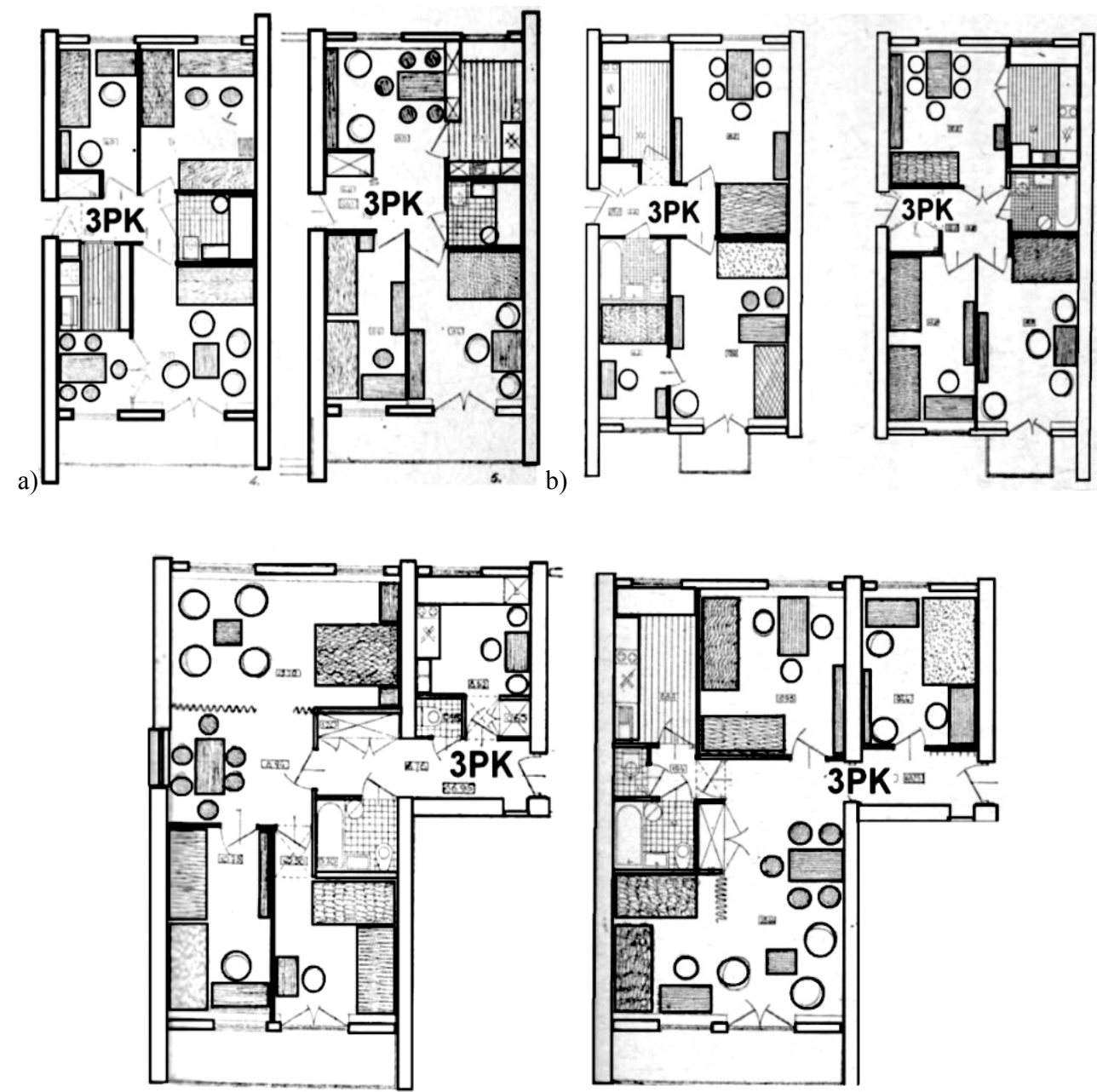

c)

d)

Fig. 7. Floor plans of apartments : a), b) - for 4 and 5 persons; c), d) - for 6 persons - Bielany II, 1958. Source: own study based on [22].

The introduction of the principle of $11.5 \mathrm{~m}^{2}$ of usable floor space per inhabitant gave Bielany II designers the opportunity to try a number of types of apartments with a variety of internal layouts. One of the most interesting attempts was to design a flat for 4 people with an area of $43.4 \mathrm{~m}^{2}$, in which there were 3 rooms $\left(17.2 \mathrm{~m}^{2}, 7.2 \mathrm{~m}^{2}\right.$ and $\left.9.4 \mathrm{~m}^{2}\right)$, kitchen $\left(4.0 \mathrm{~m}^{2}\right)$, bathroom $\left(3.2 \mathrm{~m}^{2}\right)$ and hall $\left(2.6 \mathrm{~m}^{2}\right)$. This was in contrast to the previous solutions 
from the earlier stages of implementation of the housing estate, where apartments of $40 \mathrm{~m}^{2}$ intended for 3-4 people had one room and kitchen.

Innovative solutions tried to keep up with the modern perception of how to live, where everyone had the right to their intimate place. For each type of apartment, designers predicted a number of variants (Fig. 7a, b, c, d) differing in details. After the tenants moved in, a survey was to be carried out, based on which it could be determined which variant enjoyed the greatest recognition of the inhabitants. What is interesting is the designers' approach to the common space in six-person apartments (3PK with a usable area of $66.7 \mathrm{~m}^{2}$, where the area was like a 4PK-type apartment). An innovative desire to create a multi-functional room becomes very apparent. The living room extended with bedroom areas (Fig. 7b, d) or dining rooms (Fig. 7a, c, d) could have become much more spacious considering the lean area. The situation of parents' beds in niches in living rooms reduced marital intimacy, but it definitely improved spatial comfort.

It seems that the situation was a stalemate in the face of existing surface-allocation standards and the needs of families were not satisfactorily met, to the regret of designers and sociologist researchers.

\subsection{Functional layouts of apartments in accordance with the provisions of the 1959 norm}

The design standard for apartments and residential buildings from 1959 [23] brings a breakthrough modification consisting in the introduction of apartment categories due to the number of inhabitants, not residential rooms, which theoretically gave designers greater freedom in designing apartments suitable for different types of families.

There were 7 categories of apartments - from M1 to M7. The average size of the apartment was $44 \mathrm{~m}^{2}$ (in 1959 the average size was $48.6 \mathrm{~m}^{2}$, and in $1970-43.7 \mathrm{~m}^{2}$ ). Normative regulations allowed the design of small rooms and kitchens without windows. In apartments of category above M4, an interconnecting living room with at most one sleeping space was allowed. It is not without reason that these normative arrangements have been referred to as austere. More smaller rooms (rooms) were designed on the same ZOR-like areas, which served to create individual spaces for users. The drastic reduction of the normative area per person to $7 \mathrm{~m}^{2}$ made the design of dark kitchens and interconnecting living rooms almost a necessity. This resulted in the creation of small kitchen-laboratories ${ }^{2}$, as well as a significant reduction in the area of individual rooms (up to $6 \mathrm{~m}^{2}$ ), which residents sometimes could not

\footnotetext{
${ }^{2}$ In Europe, the author of the idea of "laboratory-style" kitchens, implemented on a small area, was the Viennese architect Margarete Schütte-Lihotzky. As part of a project to build new housing estates under the name of New Frankfurt in Frankfurt am Main, in 1926, she proposed a "laboratory" kitchen model, also known as the "Frankfurt" kitchen, with an area of $6.5 \mathrm{~m}^{2}$. The presentations took place in master houses, at exhibitions, as part of lectures and press coverage, and even via a short film (in the prototype "Frankfurt kitchen", the length of the road traveled and the time spent on carrying out subsequent tasks were checked and compared to traditional kitchens). In the 1930s, Polish architects were also interested in the functionality of apartments. Famous architects Barbara and Stanisław Brukalski in the apartments on the WSM estates in Rakowiec and Żoliborz presented the idea of a small "laboratory" kitchen annex, open to the room, and modeled on the "Frankfurt" kitchen. In an effort to adapt the environment to the needs and capabilities of man, new solutions have been introduced [26]. Matching fitted furniture was used. The worktop was supplemented with standing and hanging cabinets, shelves, a sink with running water and containers for loose products with dispensers. The furniture was additionally combined with a waste bin and an ironing board folded on the wall, characteristic of the "Frankfurt" kitchen [27]. 
use. Table 1 shows the differences in normative arrangements from 1954 and 1959 regarding the area of individual rooms [24].

Table 1. Comparison of room sizes according to the norms of 1954 and 1959

\begin{tabular}{lll}
\hline room & \multicolumn{2}{l}{ surfaces of rooms according to the standards of the years } \\
\cline { 2 - 3 } & 1954 & 1959 \\
\hline kitchen & $4,5-9 \mathrm{~m}^{2}$ & $4-5 \mathrm{~m}^{2}-7 \mathrm{~m}^{2}$ \\
\hline living room & $16-20 \mathrm{~m}^{2} / 2$ sleeping areas & $12-16 \mathrm{~m}^{2} / 1$ sleeping area \\
\hline single bedroom & $10-12 \mathrm{~m}^{2}$ & $6 \mathrm{~m}^{2}$ \\
\hline double bedroom & $12-14 \mathrm{~m}^{2}$ & $9 \mathrm{~m}^{2}$ \\
\hline
\end{tabular}

Based on the new normative from 1959, architects L. Kołacz and W. Parczewski developed a design for the Szosa Krakowska housing estate in Warsaw [25]. Attention is drawn to the organization of the common living space of the apartment, where the living room connects with communication and is transitive to a small laboratory kitchen, thanks to which a more open layout was created. The communication area is minimized, which resulted in two shapely bedrooms in the M4 apartment with a usable area of $48.7 \mathrm{~m}^{2}$ (Fig. 8a).

Apartments with a small area were put into use at the Młodych estate in Warsaw's Grochów, completed in 1958-1962 (the authors of the project were arch. S. Ciechanowicz and T. Kobylański) [25]. M4 flats with a usable area of $48.7 \mathrm{~m}^{2}$ and M3 with a usable area of $39.8 \mathrm{~m}^{2}$ had a living room directly connected to the kitchen and bedroom. The kitchen was also accessible from the anteroom. This arrangement tied together the space for rest, preparation of meals and their consumption (Fig. 8b).

a)

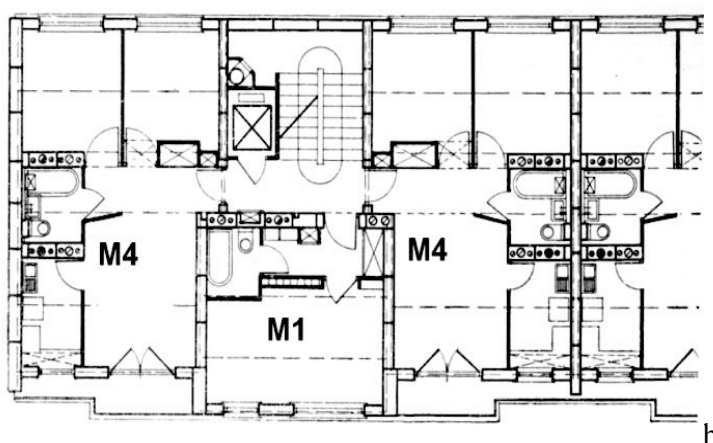

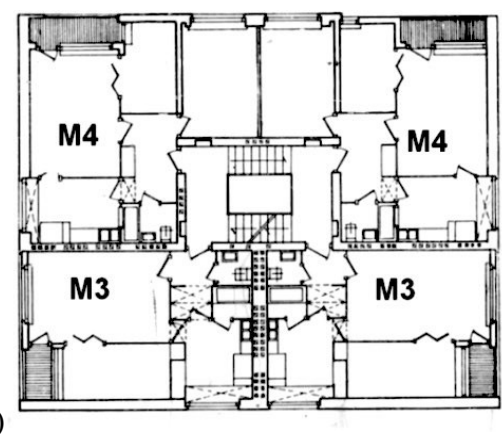

b)

Fig. 8. Floor plans of flats: a) the Szosa Krakowska housing estate, Warsaw, 1962. b) Osiedle Młodych housing estate in Warsaw, 1962. Source: own study based on [25]

A particularly interesting example of different variants of using the same types of apartments was the design of the Sady Żoliborskie housing estate in Warsaw by Hanna Skibniewska [25]. 


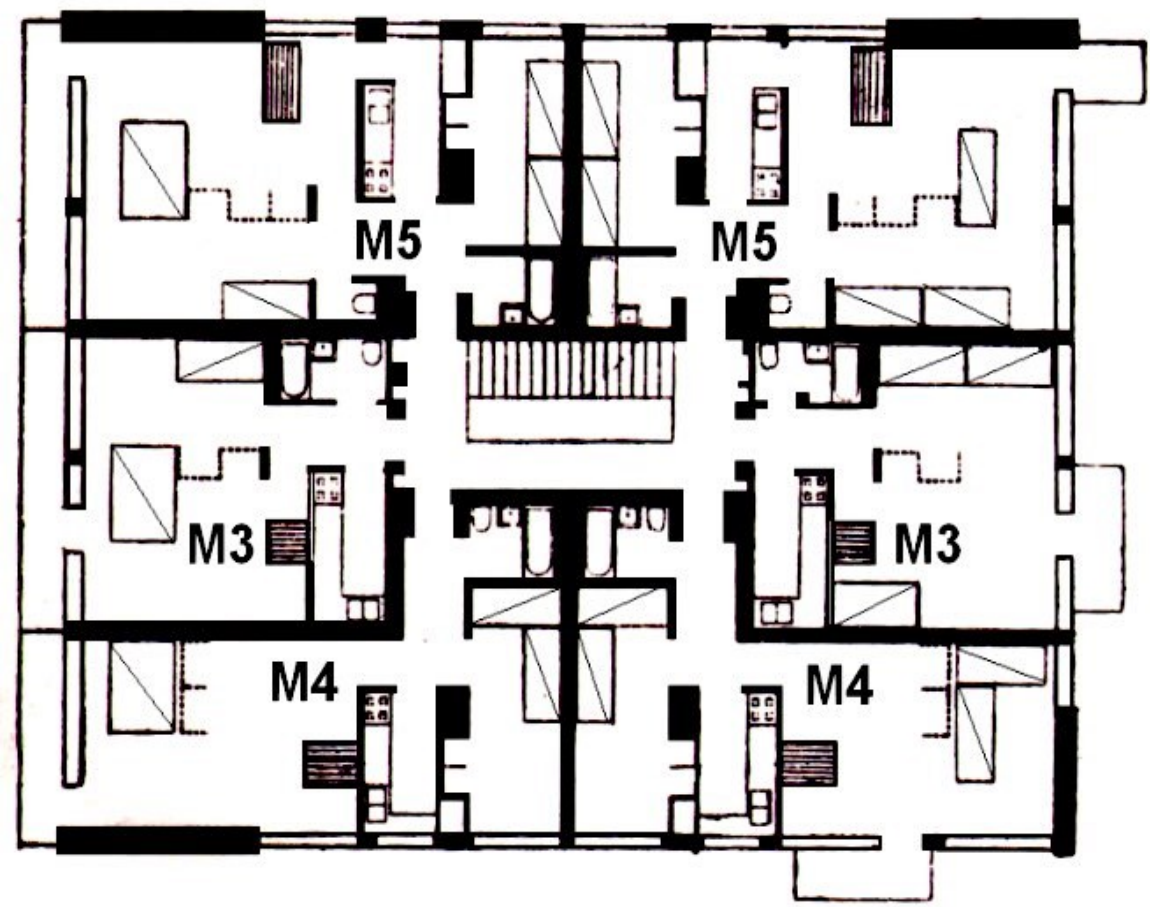

Fig. 9. Plan of the building in Sady Żoliborskie - 1963. Source: own study based on [25]

Noteworthy is the great care for the development of floor plans of flats, where wall units were arranged to divide the interiors depending on the family composition. The designer certainly knew the troubles of residents struggling with furnishing the apartments with largesize furniture. Flexible apartments with small square acreage were created: M3 - $33.8 \mathrm{~m}^{2}$, M4 - $45.5 \mathrm{~m}^{2}$ and M5 - $55.6 \mathrm{~m}^{2}$ of usable floor space. (Fig. 9). Unfortunately, due to the high costs of implementing wall units, they were replaced with ordinary partitions. Designers proposed small laboratory-type kitchens lit directly and indirectly (M3), connected to a dining area in the living room. The spacial needs of children who have a separate room here while parents sleep in the living room have been taken into account.

It is interesting (the idea often found in implemented apartments) that the proportions of separate bedrooms did not give the opportunity to arrange a marital bed (which was moreover condemned as a relic of the past) in a typical arrangement. Parents, therefore, slept in the living room area or in two beds in the bedroom. Both situations were uncomfortable and one additional room was always missing.

Various kitchen layouts were designed by architects B. Chyliński and H. Graf [28] at the Kępa Potocka housing estate in Warsaw's Żoliborz, built in 1967 in industrialized technology proposed:

- a single-line kitchen $\left(6 \mathrm{~m}^{2}\right)$ of the laboratory type with a width of $1.7 \mathrm{~m}$ in a flat M4 with a usable area of $50.6 \mathrm{~m}^{2}$ (Fig. 10a);

- a kitchen $\left(4.4 \mathrm{~m}^{2}\right)$, indirectly lit and separated from the room by a wall unit in a M3 apartment with a usable area of $39.6 \mathrm{~m}^{2}$ (Fig.10b);

- a small kitchen $\left(3.2 \mathrm{~m}^{2}\right)$ accessible from the room in the M2 apartment with a usable area of $27.6 \mathrm{~m}^{2}$ (Fig.10a);

- a dark kitchenette $\left(2.5 \mathrm{~m}^{2}\right)$ in the apartment M2 - $21 \mathrm{~m}^{2}$ (Fig.10a). 


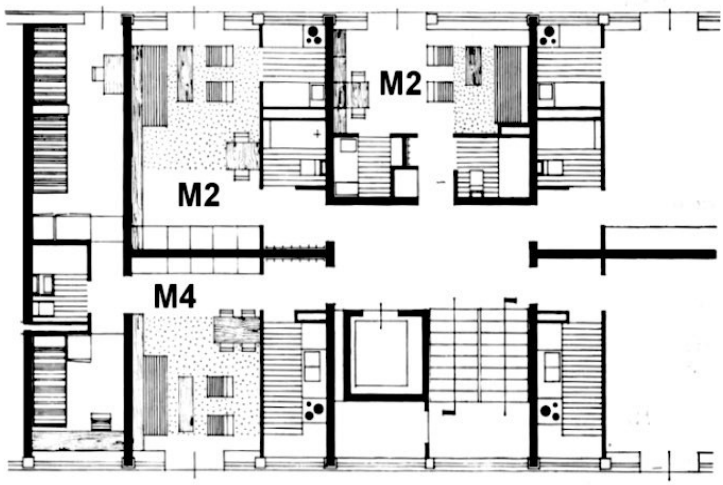

a)

b)
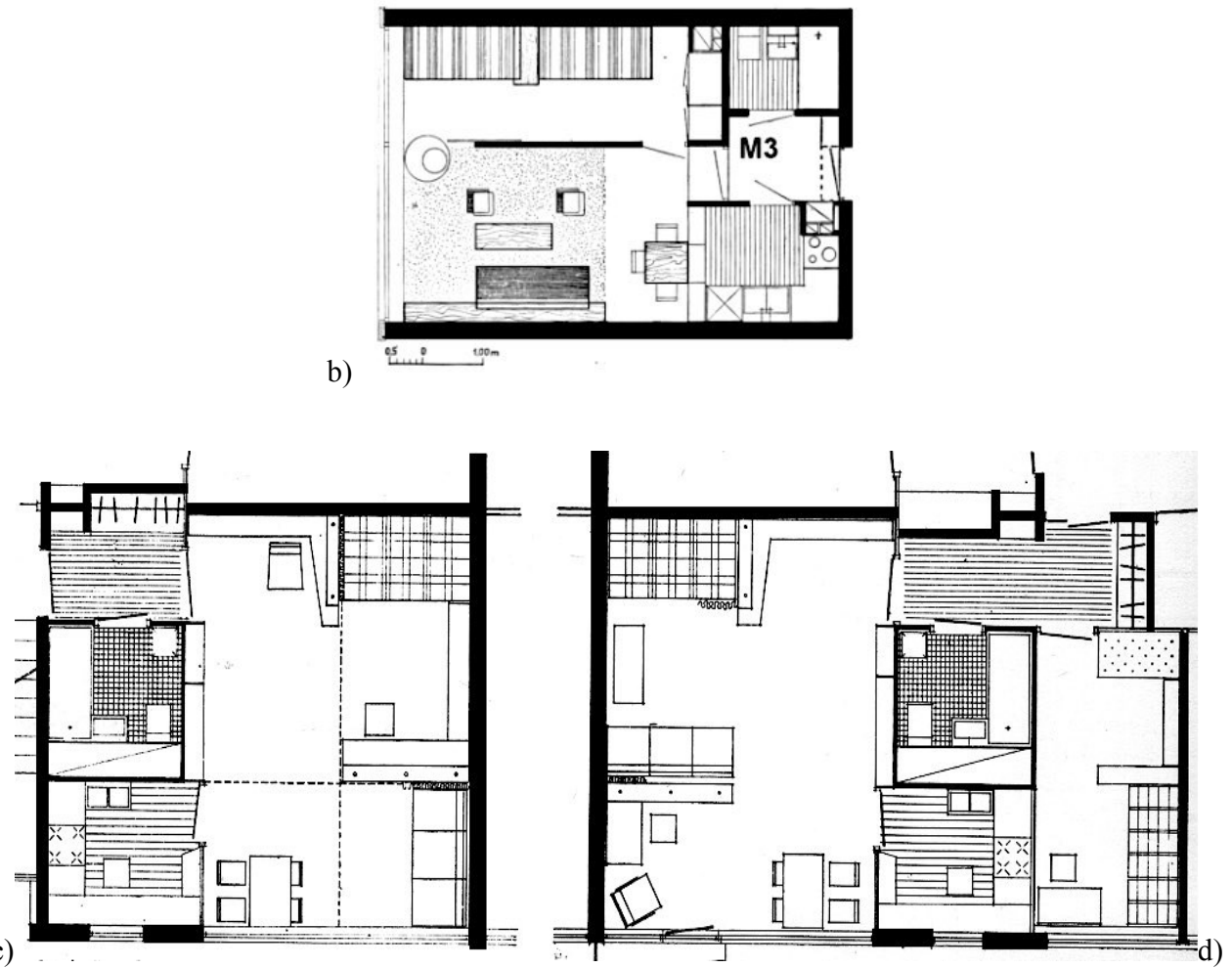

Fig. 10. a, b, c. Floor plans of apartments in Kępa Potocka, 1967. Source: own study based on [28]

Analyzing the functional arrangement of apartments M4 and M3, one can notice some inconsistencies in the location of sleeping areas:

- in the M4 apartment (for a family with two children - Fig. 10a) there are two bedrooms, while their proportions allow placing the beds only along the wall. The architect's idea is not clear - is the room with two beds the parents' bedroom (there 
is no traditional way to arrange a double bed) or the children's room, and then the parents sleep in the living room?

- in the second case, parents sleep in a small room or on a sofa bed in the room; in the M3 apartment (for parents with a child - Fig.10b), the situation is also unclear - whether the narrow niche is intended for parents and the sofa is used for the child's sleeping area, or whether the architect thought about two children and parents sleeping in the living room. This ambiguity indicates great difficulty in design decisions made by architects. In the existing legal situation, it was impossible to meet all the needs of tenants.

It is worth noting the detailed interior design - appropriate for emerging stylistically new furniture available in stores. Already at project construction stage, designers show tenants the various options of furnishing small apartments. Wall units were used - with built-in tables, desks or couches - set against the walls as well as dividing the room into two zones (Fig.10c).

The residents' assessment of their apartments was quite changeable - from positive in the early 1950 s to negative in the 1960s. Although the apartments from the early 1950s were small - one- or two-room, they met the users' expectations, especially thanks to the relatively spacious kitchens, where the family life mainly concentrated. The lowering of the construction and housing standard in the 1960s, caused by normative provisions of 1959, was met by far negatively by society, because it contradicted the belief of socio-economic development taking place and the perceptible improvement of the economic situation of Polish society. Instead of the expected transition from a very modest standard to standards corresponding to social development - there was a regression (the average usable floor space of an apartment completed in 1950 in cities was $47.9 \mathrm{~m}^{2}$, in $1960-46.9 \mathrm{~m}^{2}$, in $1965-43.4$ $\mathrm{m}^{2}$, in $1970-42.8 \mathrm{~m}^{2}$ ).

\section{Summary and Conclusions}

\subsection{Summary}

Architects were a very important link in the process of shaping the awareness of housing culture. It was them, limited by the technology of building construction and norms, created functional layouts of apartments, mainly taking into account the needs of future residents. Users had to get used to and accept smaller and smaller living spaces. Designers were tasked to help them in this process.

An analysis of the functional layouts of apartments in newly established estates indicates a clear transition from layouts with relatively large kitchens and rooms (in the 1950s) to divisions into a larger number of smaller rooms due to the need to isolate family members (in the 1960s). In the late 1950s, architects worked on improving the utility value of apartments, paying attention to the varying needs of different groups of residents.

The main trends in the design of the apartment space were:

1. Increasing the area of the day zone (as part of the applicable normative provisions)

- bedroom areas were designed in living rooms, where, after opening them to the living room, more interior space could be obtained,

- the space was connected by placing doors also between rooms,

- attempts were made to create a multifunctional room - a non-traditional spatial arrangement was used (in traditional rooms we enter from a separate hall), in which the living room space from the entrance connects with communication, sometimes with the kitchen, which is a new, more open approach to the living zone of the apartment. 
2. Propagating flexible interior design - multi-functional furniture separating individual rooms was introduced.

3. Searching for optimal kitchen solutions:

- a kitchen with an arranged dining area which was a response to the clear preferences of users;

- the modern model of dining in the living room was clearly promoted, and it was even experimentally proposed to connect the kitchen with the living room through a door, a feeding window, a double-sided sideboard or a dining room.

4. Searching for optimal solutions in the arrangement of sleeping areas, which was probably the result of a clash of views on this topic and on the issue of the child's place in the space of the apartment. At the beginning of the 1950s, all household members were sleeping in the bedroom, and in time, the need for individual spaces (especially in white-collar environments) for parents and children arose. The following options were considered:

- children have their own room (and even separate rooms), while parents occupy fold-out beds in the living room (separate spaces are designed),

- a favorable solution, in which parents have a separate bedroom (unfortunately, often its proportions make it impossible to put the marital bed in the traditional way) and the children their room,

- a controversial solution - parents have their own bedroom, while children are expected to sleep in the living room in separate areas,

- placing sleeping areas with attention to parents' comfort, creating bedrooms even in the vicinity of sanitary blocks.

5. The introduction of bathroom areas with a separate toilet, which allowed to put a washing machine in the bathroom and enabled a family of several people to use the bathroom almost without interference.

\subsection{Conclusions}

The architects' design decisions were a consequence of government policy. However, the quality of functional solutions of the designed apartments depended on the knowledge, talents and diligence of the architects. The development of design thought in project ideas - especially in the late 1950s - not only led to changes in the spatial structure of apartments, but also changed the awareness of society's housing needs and habits in the organization of housing functions. It initiated the evolution of cultural patterns in the use of housing. Too small laboratory-style kitchens did not allow for placing a dining table there. Worker families were forced to eat in the living room, thus breaking the rural (traditional) pattern of the home. The new apartments did not provide adequate spatial conditions for cultivating the traditional rural pattern, which as a result was gradually disappearing. Families of white-collar workers - representing the middle-class pattern of apartment use - provided children with separate rooms. They deplored the need to sleep in the living room, which in previous environments would have been unacceptable. Architects' design decisions have certainly contributed to the shaping of a modern space management model in families with more democratic relationships between parents and children. 


\section{References}

[1] Syrkusowie H. i S., "Budownictwo mieszkaniowe z elementów wielkopłytowych", „Architektura” nr 7/1957, p. 263

[2] Dobrzyńska M., Malicki Z., "Osiedle Warszawskiej Spółdzielni Mieszkaniowej na Rakowcu”, „Architektura” nr 7/1959, p. 297

[3] Wiking.edu, Demografia Polski,www.wiking.edu.pl/article.php?id=269, [Accessed: 5 Sept 2019]

[4] Główny Urząd Statystyczny, Rocznik Statystyczny 1980. Rok XL, GUS, Warszawa, p. 42

[5] Główny Urząd Statystyczny, Rocznik Statystyczny 1986. Rok XLVI, GUS, Warszawa, p. 39

[6] Litterer W. , "Nowe osiedla mieszkaniowe i ich mieszkańcy", Polskie Wydawnictwa Gospodarcze, Warszawa 1952

[7] Malicka W., "Próba analizy graficznej użytkowania mieszkań.[in:] Zaludnienie i użytkowanie mieszkań w nowych osiedlach”, IBM, Warszawa 1959

[8] Czeczerda W., "Ludność w nowych zespołach mieszkaniowych”, IBM, Warszawa 1959

[9] Putowska J., "Jak urządzić mieszkanie”, Arkady, Warszawa 1960, p. 12

[10] Matejko A., "Wartość użytkowa nowych mieszkań w świetle doświadczeń ich mieszkańców”, in: Zaludnienie i użytkowanie mieszkań w nowych osiedlach, red. Wł. Czajka, IBM, Arkady, Warszawa 1959, p. 65

[11] Turowski J., "Środowisko mieszkalne w świadomości ludności miejskiej”, Ossolineum, Wrocław, Warszawa, Kraków, Gdańsk 1979, p. 44

[12] Nowicki J., "Standard i przestrzenne rozwiązania w spółdzielczym budownictwie mieszkaniowym”, „Sprawy Mieszkaniowe” z. 4/1993, p. 57

[13] Ustawa z dnia 3 lipca 1947 roku „O normach i standardach budowlanych”, Dziennik Ustaw 1947 nr 52, poz. 269

[14] Korzeniewski W., "Mieszkania społecznie najpotrzebniejsze. Wczoraj i dzisiaj”, Źródło: cejsh.icm.edu.pl/cejsh/element/bwmeta1...PRM_2009-1-2_04_Korzeniewski.pdf [Accessed: 1 Oct 1916)

[15] Uchwała nr 612 Rady Ministrów z dnia 18 sierpnia 1951 r., „Normatyw projektowania budynków mieszkalnych i mieszkań w miastach i osiedlach typu miejskiego"

[16] Lachert B., "Muranów-Dzielnica Mieszkaniowa”, „Architektura” nr 5/1949, p. 134

[17] Piotrowski W., “Osiedle mieszkaniowe Praga II”, „Architektura” nr 7-8/1952, p. 191

[18] Uchwała nr 70 Prezydium Rządu z dnia 6 lutego 1954 r., Normatyw projektowania budynków mieszkalnych i mieszkań w miastach i osiedlach typu miejskiego, , „Monitor Polski” nr 120, Warszawa 1954

[19] Kleyff Z., Osiedle doświadczalne przy ul. Kasprzaka w Warszawie, „Architektura” nr 8/1958, pp.309-314.

[20] Matejko A., “O użytkowaniu mieszkań”, „Architektura” nr 5/1957, p. 196

[21] Fafius Z., “Osiedle Wierzbno”, „Architektura” nr 9/1958, pp. 253-263

[22] Lewandowski T., "Bielany”, „Architektura” nr 7/1958, p. 285

[23] Uchwała nr 364 Rady Ministrów z dnia 20 sierpnia 1959 r., Normatyw projektowania mieszkań i budynków mieszkalnych wielorodzinnych w miastach i osiedlach, , „Monitor Polski” nr 81, Warszawa 1959

[24] Płachcińska A., "Standard w społecznym budownictwie mieszkaniowym”, „Sprawy Mieszkaniowe" nr 2, IGM, Warszawa 1994, p.9

[25] Filipow Z. "Budownictwo mieszkaniowe w Warszawie”, „Architektura” nr 1-2/1963, pp. 10, 21, 24 
[26] Charytonowicz J., "Dokąd zmierza współczesna ergonomia. Wybrane kierunki badań ergonomicznych w 2008 roku", JAKS, Wrocław 2008, p. 15

[27] Nowakowski P., "Architektura i ergonomia kuchni domowych na tle ewolucji zwyczajów kulinarnych", Oficyna Wydawnicza Politechniki Wrocławskiej, Wrocław 2015, p. 44. doi:10.5277/Y03.2015.01

[28] Graf H., “Osiedle Kępa Potocka”, „Architektura” nr 5-6/1967, pp.195-199 